\title{
Testing for Market Efficiency in Emerging Markets: A Case Study of the Karachi Stock Market
}

\author{
Khalid Mustafa" and Mohammed Nishat"
}

\begin{abstract}
This paper investigates the efficiency of the Karachi stock exchange (KSE) with corrections for thin trading and non-linearity as suggested by Miller, Muthuswamy and Whaley (1994). Daily, weekly, and monthly data on stock prices from December 1991 to May 2003 have been used, with three non-overlapping periods (December 1991 to May 1998; May 1998 to September 2001; and September 2001 to May 2003) and one combined period (May 1998 to May 2003). The results indicate that the Karachi Stock Market is efficient for the overall period, the three sub-periods, and the combined period in linear and non-linear behavior after making adjustments for thin trading. The same result is observed when the efficiency test is conducted on weekly and monthly data after adjusting for thin trading during the overall study period.
\end{abstract}

\section{Introduction}

The globalization of financial markets has increased the interest of investors in emerging markets. Many studies have commented on the predictability of returns in emerging markets e.g. (Urrutia, 1995; Ojah and Karemera, 1999; and Grieb and Reyes, 1999). However, different conclusions are drawn on market efficiency and the random walk hypothesis in these studies. Urrutia (1995) rejects the random walk hypothesis; however, he advocates for weak form efficiency. Ojah and Karemera (1999) indicated that equity returns in these markets follow a random walk. Branes (1986), Butler and Malaikah (1992), E1-Erian and Kumar (1995) and Anotoniou and Ergul (1997) found inefficient behavior in the stock markets of Kuala Lumpur, Saudi Arabia, Turkey, Jordan, and Istanbul respectively. On the other hand, Butler and Malaikah (1992), Panas (1990) and Dickinson

\footnotetext{
* Assistant Professor, Department of Economics, University of Karachi

* PhD, Professor and Chairman, Finance and Economics, Institute of Business Administration, Karachi
} 
and Muragu (1994) found efficient stock markets in several emerging markets (Kuwait, Greece and Nairobi). Furthermore, investors in emerging markets are mostly concerned with losses as compared to gains, which leads to risk neutral behavior (Benartzi and Thaler 1995). Investors believe in their own forecasting, which leads to bias in prediction (Dabbs, Smith, and Procato, 1990). Investors are also less informed, which affects on trading behavior (Schatzberg and Reiber, 1992).

Infrequent trading behaviour, observed in most emerging markets, has two forms. Firstly, there is non-synchronous trading in which stocks trade every consecutive interval, but not necessarily at the close of each interval [Scholes (1976), Scholes and Williams (1977) and Muthuswamy (1990)]. The other form is infrequent trading in which stocks are not traded in every consecutive interval. Fisher (1996), Dimson (1979), Cohen, Maier, Schwartz, and Whitcomb, (1978), Cohen $(1978,1979)$ Lo and Mackinlay (1990), and Stoll and Whaley (1990b) focus on this infrequent trading. The key to distinguish between non-synchronous trading and infrequent trading is the interval over which price changes or returns are computed. In the literature it is observed that due to the problem of infrequent trading, the true prices may be contaminated as pointed out by Roll (1984) and developed by Stoll and Whaley (1990). They demonstrated that random bouncing of transaction prices between bid and ask, induces negative firstorder autocorrelation in observed price changes even though price innovations are serially independent.

A number of studies have suggested ways to correct for infrequent trading. Stoll and Whaley (1990) suggested the residuals from an ARMA $(\mathrm{p}, \mathrm{q})$ regressions as a proxy for the true index. Bassett, France and Pliska (1991) used the Kalman filter to estimate a distribution of the true index. Miller, Muthuswamy and Whaley (1994) proposed to remove the effects of thin trading by using moving averages, which reflects the number of nontrading days, and then returns are adjusted accordingly. Butler and Malaikah (1992) ran tests to evaluate the weak form efficiency of the stock markets in Saudi Arabia and Kuwait. A1-Loughani (1995) suggested statistical techniques for the Kuwaiti market index and concluded that the series exhibited stationarity but did not conform to the random walk model. Most of these studies have attempted to correct for the problems associated with infrequent trading.

The Karachi stock market is one of the leading emerging markets. There are 659 companies listed in the Karachi stock exchange (KSE) with a total market capitalization of about $\$ 34.7$ million, amounting to 25 
percent of the GDP in Pakistan. ${ }^{48}$ This feature of the KSE indicates a shallow market with high turnover, common features amongst emerging stock markets. The reasons for the shallowness of the market and high levels of turnover in emerging markets are poor information, insider trading, liquidity, and market manipulation. In general, the KSE has demonstrated significant fluctuations since reforms during 1990s (see figure 1). Only a few studies have looked at the behavior of the Karachi stock market. Hussain (1997) investigated the validity of the random walk model in the Pakistani equity market using daily data from January 1989 to December 1993. He found the presence of strong serial dependence in stock returns and suggested that the random walk model was not appropriate to describe stock returns behavior in the Pakistani equity market. However, his study did not take into consideration the special characteristics of the Karachi stock market as an emerging market. Nishat $(1999,2001)$ also pointed out the ARCH effect and non-synchronous effect in the Karachi stock market (also see Pakistan Economic Survey, 2005-6 pp. 108 , which indicates that $62.4 \%$ trading volume are shared by 10 big companies listed with KSE). Moreover, researchers (Nishat, 1999; Nishat, 2000; Nishat and Mustafa, 2007) have identified a change in the behaviour of stock prices and a shift in the pattern of observed anomalies after the financial reforms of $1990 \mathrm{~s}$. These financial reforms provided depth and breadth in the Karachi stock market and a more competitive environment for investors in Pakistan (Nishat, 2001).

The aim of this study is to investigate the validity of the random walk model for the Karachi stock market taking into consideration the characteristics of emerging markets for the period December 1991 to May 2003. These characteristics are thin trading and non-linearity in the behavior of the stock market. The KSE has also been influenced by events such as sanctions on the Pakistani economy after the nuclear tests in May 1998 and 9/11, leading to a change in the price process of the stock market. The study also compares random walk model before and after nuclear tests (May 1998) and 9/11 (September 2001). The rest of the paper is organized as follows: The second section describes the econometric methodology and related issues followed by data in section three. The empirical findings and interpretation are presented in section four. Section five provides the concluding remarks.

\footnotetext{
${ }^{48}$ In developed markets, the market capitalization ratio to GDP is large and turnover is small. The Pakistan stock market stands in contrast to developed markets like the US, where the market capitalization to GDP ratio is 92 percent and turnover is 65 percent.
} 


\section{Figure-1}

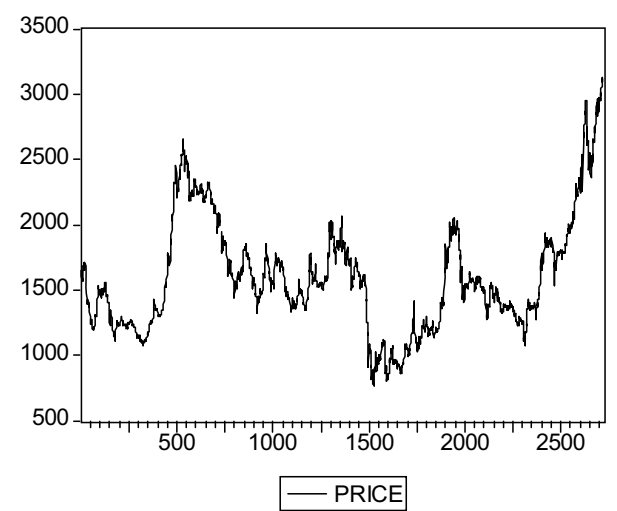

\section{Econometric Methodology}

To test for efficiency in the Karachi stock market, we use the methodology proposed by Miller, Muthuswamy and Whaley (1994) to check the efficiency of the stock market taking into consideration thin trading, non-linearity, and structural changes. Returns are calculated by the difference of two successive $\log$ daily price of the KSE-100 index:

$$
\mathrm{R}_{\mathrm{t}}=\ln \mathrm{P}_{\mathrm{t}}-\ln \mathrm{P}_{\mathrm{t}-1}
$$

where $P_{t}$ is the current KSE-100 index and $P_{t-1}$ is the previous day's KSE-100 index.

Because thin trading, possibility of non-linearity, and structural changes are considered, making it difficult to identify the number of trading days, Miller (1990) has shown that it is equivalent to estimating an AR(1) model from which the non-trading adjustment can be obtained. The following equation is estimated:

$$
R_{t}=\alpha_{0}+\alpha_{1} R_{t-1}+\varepsilon_{t}
$$

The regression of $\mathrm{R}_{t}$ on $\mathrm{R}_{\mathrm{t}-1}$ shows the negative first order autocorrelation. In this situation, we expect that there is infrequent trading. This is dealt with by taking the residual from the regression to generate the innovations in the KSE-100 level. The returns are adjusted by using following equation suggested by Miller, Muthuswamy and Whaley (1994): 


$$
R_{t}^{a d j}=\frac{\varepsilon_{t}}{1-\alpha_{1}}
$$

where $\varepsilon_{\mathrm{t}}$ is the adjustment factor and $R_{t}^{a d j}$ is the adjusted return.

This adjustment reduces the negative correlations among the returns with the assumption that the non-trading adjustment is constant over time. However, this assumption is correct only for highly liquid markets, not for emerging markets. To correct for thin trading, we must estimate equation (3) recursively. In testing for efficiency, equation (2) is estimated using corrected returns calculated from equation (3). Moreover, efficiency will be examined using linear and non-linear models to see if the results of the two models are different. For this purpose the following equation is estimated:

$$
\mathrm{R}_{\mathrm{t}}=\alpha_{0}+\alpha_{1} \mathrm{R}_{\mathrm{t}-1}+\alpha_{2} \mathrm{R}_{\mathrm{t}-1}^{2}+\alpha_{3} \mathrm{R}_{\mathrm{t}-1}^{3}+v_{\mathrm{t}}
$$

In the case of thin trading and non-linearity we estimate the following equation:

$$
R_{t}^{a d j}=\frac{v_{t}}{1-\alpha_{1}}
$$

To correct for thin trading, equation 5 is run recursively. In testing for efficiency equation (6) is estimated using corrected returns calculated from equation (5):

$$
R_{t}^{a d j}=\alpha_{0}+\alpha_{1} R+\alpha_{2} R_{t-1}^{a d j}+\alpha_{3} R_{t-1}^{a d j}+u_{t}
$$

\section{Data}

The data used in this study is daily KSE-100 index data from December 1991 to May 2003, taken from various issues of Daily Business Recorder. The return is calculated by the difference of $\log$ of two successive KSE-100 indexes by equation (1).

\section{Empirical Results}

The random walk models, taking into account thin trading and nonlinearity, are estimated using OLS. Table- 1 shows the test of the random walk model on daily data (without non-linearity) for uncorrelated returns of the KSE-100 index. We considered the full sample period from December 1991 to May 2003, three sub-sample non-overlapping periods (December 
1991 to May 1998; May, 1998 to September, 2001; and September, 2001 to May 2003) ${ }^{49}$, and one combined period (May, 1998 to May, 2003). In all periods and all sub-sample periods, the results indicate that the estimated coefficients are statistically significant. This shows that the Karachi stock was inefficient during the study period before adjustment for thin trading. It also implies that the Karachi stock market did not follow the random walk hypothesis. It also shows that the effects of thin trading are an important factor in the efficiency of Karachi stock market. However, results from the combined period (May 1998 - May 2003) gave evidence for the efficiency of the Karachi stock markets i.e. supported the random walk hypothesis. A possible reason is that information on the stock market had become more easily available due to the internet, cable, television and newspapers.

We also examined the random walk model by testing it on weekly and monthly data (with linearity) for uncorrelated returns at the KSE-100 index (see Table 5 and 9). The result is the same as we found in the daily data. However, unlike the daily data, we found a significant relationship between two successive prices in the combined period. This implies that the stock market does not follow a random walk in the weekly and monthly data. The reasons may be that monthly and weekly data adjust to new information more easily as compared to the weekly and daily data on stock market activity and it may falsely portray an efficient stock market. Jun and Uppal (1994) pointed out that monthly data can lead to spurious conclusions about the efficiency of markets due to adjustment of information.

To consider the impact of non-linear returns due to less informed investors, biased forecasts of investors, and neutral risk behaviour (that affects the efficiency of Karachi stock market), the non-linear model has been estimated on the basis of daily, weekly, and monthly data. The results are presented in Tables 3, 7 and 11, which indicate that the KSE is inefficient when tested with a non-linear model on daily and weekly data in the full sample period and two sub-sample periods. This implies that the Karachi stock market does not follow the random walk model even we consider the non-linear characteristic of emerging markets in these periods. However, in one sub-sample period and the combined period, the KSE-100 index is efficient and follows the random walk model. These two periods are related to the events of September 11, 2001. In these periods, there is a significant role for information on financial markets. In the case of monthly

\footnotetext{
${ }^{49}$ During the sample there are two events that had considerable impacts on the Pakistan's economy. These events were the May 1998 nuclear test and September 11, 2001. As a result Pakistan's economy went into depression.
} 
data, it indicates that the stock market is efficient for the full sample period, the three sub-sample periods, and the combined period.

The results for model adjusted for thin trading in linear and nonlinear model are presented in Table- 2 and 4 for daily data, table 6 and 8 for weekly data and Table-10 and 12 for monthly data. After the adjustment for thin trading in the linear model on the basis of daily data, weekly data and monthly data, the results show that the KSE is efficient during the study period for the full sample as well as for three sub-sub sample periods. However, the KSE is inefficient after the nuclear test of May 28, 1998 in daily data only. The inefficiency is likely the effect of the nuclear test and $9 / 11 / 2001$. The estimated coefficients obtained by both techniques are statistically not different from zero. This indicates that the KSE is efficient during the study period after adjustments for thin trading. It is evident that the coefficient of the non-linear term is insignificant in all three type data. This implies that the return generating process in KSE is non-linear. It concludes that when thin trading is adjusted in a non-linear model, the Karachi Stock exchange exhibits efficient behavior in daily data, weekly data, and monthly data.

\section{Summary and Concluding Remarks}

This study has empirically investigated the efficiency of the Karachi stock market. The random walk hypothesis was tested on daily, weekly and monthly data from December 1991 to May 2003 with three non-overlapping periods and one combined period. The empirical results indicated that, without taking into consideration thin trading and non-linearity, the Karachi stock market was inefficient in all three types of data. This implies that the Karachi stock market did not follow the random walk model. However, when the returns were adjusted for thin trading and non-linearity, the Karachi stock market revealed efficient behavior and followed the random walk model for the full sample period (December 1991 to May 2003) and all sub-sample periods ((December 1991 to May 1998; May 1998 to September 2001; and September 2001 to May 2003), but not for the combined sample period (May 1998 to May 2003). This shows that when thin trading is adjusted for in a non-linear random walk model, the results show a greater degree of stock market efficiency than in the unadjusted specifications. 
Table-1: Random Walk Model with out non-linearities for uncorrected returns for KSE-100 index on daily basis

$$
R_{t}=\alpha_{0}+\alpha_{1} R_{t-1}+\varepsilon_{t}
$$

\begin{tabular}{|c|c|c|c|c|c|}
\hline Periods & $\alpha_{0}$ & $\alpha_{1}$ & $\chi^{2 a}$ & Q-stats & $\chi^{2 b}$ \\
\hline $\begin{array}{c}\text { Dec. } 14,1991 \\
\text { to } \\
\text { May } 30,2003\end{array}$ & $\begin{array}{l}0.000 \\
(0.66)\end{array}$ & $\begin{array}{l}0.084 \\
(4.39)\end{array}$ & 218.87 & 53 & $\begin{array}{c}\chi^{2}=39.29 \\
\mathrm{~F}=19.76\end{array}$ \\
\hline $\begin{array}{c}\text { Dec. } 14,1991 \\
\text { to } \\
\text { May } 28,2003\end{array}$ & $\begin{array}{l}-0.000 \\
(-0.64)\end{array}$ & $\begin{array}{l}0.219 \\
(8.64)\end{array}$ & 86.24 & 25 & $\begin{array}{c}\chi^{2}=42.86 \\
F=21.68\end{array}$ \\
\hline $\begin{array}{c}\text { May } \begin{array}{c}29, \\
\text { to }\end{array} \\
\text { Sept. } 11,2001\end{array}$ & $\begin{array}{l}0.000 \\
(0.29)\end{array}$ & $\begin{array}{l}0.062 \\
(1.77)\end{array}$ & 28.76 & - & $\begin{array}{c}\chi^{2}=8.55 \\
\mathrm{~F}=4.27\end{array}$ \\
\hline $\begin{array}{c}\text { Sept. } 12,2001 \\
\text { to } \\
\text { May } 30,2003\end{array}$ & $\begin{array}{c}0.002 \\
(2.51)\end{array}$ & $\begin{array}{l}-0.125 \\
(-2.51)\end{array}$ & 98.90 & - & $\begin{array}{c}\chi^{2}=27.63 \\
F=14.14\end{array}$ \\
\hline $\begin{array}{c}\text { May } 28,1998 \\
\text { to } \\
\text { May 30, } 2003\end{array}$ & $\begin{array}{l}0.000 \\
(1.48)\end{array}$ & $\begin{array}{l}0.006 \\
(0.13)\end{array}$ & 99.80 & - & $\begin{array}{c}\chi^{2}=14.41 \\
F=7.22\end{array}$ \\
\hline
\end{tabular}

a. White test for hetroscedasticity. $\mathrm{H}_{0}$ : is the series is homoscedastic. $\mathrm{H}_{1}$. is other wise.

b. Ramsey RESET Test. $\mathrm{H}_{0}$ : the functional form is correct. $\mathrm{H}_{1}$ : otherwise. 
Table-2: Random Walk Model with out non-linearities for corrected returns for KSE-100 index on daily basis

$R^{\mathrm{adj}}=\alpha_{0}+\alpha_{1} R^{\mathrm{adj}}{ }_{\mathrm{t}-1}+\varepsilon_{\mathrm{t}}$

\begin{tabular}{cccccc}
\hline Periods & $\alpha_{0}$ & $\alpha_{1}$ & $\chi^{2 \mathrm{a}}$ & Q-stats & $\chi^{2 \mathrm{~b}}$ \\
\hline $\begin{array}{c}\text { Dec. 14, 1991 } \\
\text { to }\end{array}$ & $\begin{array}{c}0.000 \\
(0.00)\end{array}$ & $\begin{array}{c}-0.015 \\
(-0.78)\end{array}$ & 203.78 & 55 & $\chi^{2}=34.04$ \\
May 30, 2003 & & & & $\mathrm{F}=17.09$ \\
Dec. 14, 1991 & 0.000 & -0.015 & 19.98 & 35 & $\chi^{2}=42.99$ \\
to & $(0.00)$ & $(-0.58)$ & & & $\mathrm{F}=21.75$ \\
May 28, 2003 & & & & & \\
May 29, 1998 & -0.000 & -0.019 & 21.73 & - & $\chi^{2}=8.11$ \\
to & $(0.21)$ & $(-0.55)$ & & & $\mathrm{F}=4.06$ \\
$\begin{array}{c}\text { Sept. 11, 2001 } \\
\text { Sept. 12, 2001 }\end{array}$ & 0.000 & 0.002 & 108.91 & - & $\chi^{2}=28.60$ \\
to & $(0.10)$ & $(0.06)$ & & & $\mathrm{F}=14.66$ \\
$\begin{array}{c}\text { May 30, 2003 } \\
\text { May 28, 1998 }\end{array}$ & 0.000 & 0.047 & 92.129 & - & $\chi^{2}=3.20$ \\
to & $(0.02)$ & $(1.76)$ & & & $\mathrm{F}=6.61$ \\
May 30, 2003 & & & & & \\
\hline
\end{tabular}

a. White test for hetroscedasticity. $\mathrm{H}_{0}$ : is the series is homoscedastic. $\mathrm{H}_{1}$.is other wise.

b. Ramsey RESET Test. $\mathrm{H}_{0}$ : the functional form is correct. $\mathrm{H}_{1}$ : otherwise. 
Table-3: Random Walk Model with non-linearities for uncorrected returns for KSE-100 index on daily basis

$$
\mathbf{R}_{\mathrm{t}}=\alpha_{0}+\alpha_{1} \mathbf{R}_{\mathrm{t}-1}+\alpha_{2} \mathbf{R}_{\mathrm{t}-1}^{2}+\alpha_{3} \mathbf{R}_{\mathrm{t}-1}^{3}+\varepsilon_{\mathrm{t}}
$$

\begin{tabular}{ccccccc}
\hline Periods & $\alpha_{0}$ & $\alpha_{1}$ & $\alpha_{2}$ & $\alpha_{3}$ & $\chi^{2 \mathrm{a}}$ & $\chi^{2 \mathrm{~b}}$ \\
\hline $\begin{array}{c}\text { Dec. 14, 1991 } \\
\text { to }\end{array}$ & -0.000 & 0.161 & 0.904 & -22.599 & 245.144 & $\chi^{2}=37.78$ \\
$(-0.18)$ & $(7.08)$ & $(2.58)$ & $(-6.198)$ & & $\mathrm{F}=12.64$ \\
May 30, 2003 & & & & & & \\
Dec. 14, 1991 & -0.000 & 0.341 & -2.715 & -92.57 & 38.70 & $\chi^{2}=19.43$ \\
to & $(0.82)$ & $(10.72)$ & $(-3.54)$ & $(-16.72)$ & & $\mathrm{F}=6.48$ \\
$\begin{array}{c}\text { May 28, 2003 } \\
\text { May 29, 1998 }\end{array}$ & 0.000 & 0.147 & -0.131 & -21.166 & 67.57 & $\chi^{2}=5.01$ \\
to & $(0.28)$ & $(3.23)$ & $(-0.225)$ & $(-2.92)$ & & $\mathrm{F}=1.66$ \\
$\begin{array}{c}\text { Sept. 11, 2001 } \\
\text { Sept. 12, 2001 }\end{array}$ & 0.002 & -0.099 & -1.066 & 21.305 & 51.62 & $\chi^{2}=39.71$ \\
to & $(2.20)$ & $(-1.21)$ & $(-0.775)$ & $(0.765)$ & & $\mathrm{F}=13.65$ \\
$\begin{array}{c}\text { May 30, 2003 } \\
\text { May 28, 1998 }\end{array}$ & 0.000 & 0.101 & -0.261 & -17.055 & 116.66 & $\chi^{2}=31.89$ \\
to & $(1.14)$ & $(2.59)$ & $(-0.49)$ & $(-2.54)$ & & $\mathrm{F}=10.71$ \\
May 30, 2003 & & & & & & \\
\hline
\end{tabular}

a. White test for hetroscedasticity. $\mathrm{H}_{0}$ : is the series is homoscedastic. $\mathrm{H}_{1}$.is other wise.

b. Ramsey RESET Test. $\mathrm{H}_{0}$ : the functional form is correct. $\mathrm{H}_{1}$ : otherwise. 
Table-4: Random Walk Model with non-linearities for corrected returns for KSE-100 index on daily basis

$R^{\text {adj }}=\alpha_{0}+\alpha_{1} R^{\text {adj }}{ }_{\mathrm{t}-1}+\alpha_{2} R^{\mathrm{adj} 2}{ }_{\mathrm{t}-1}+\alpha_{3} \mathrm{R}_{\mathrm{t}-1}^{\mathrm{adj} 3}+\varepsilon_{\mathrm{t}}$

\begin{tabular}{ccccccc}
\hline Periods & $\alpha_{0}$ & $\alpha_{1}$ & $\alpha_{2}$ & $\alpha_{3}$ & $\chi^{2 \mathrm{a}}$ & $\chi^{2 \mathrm{~b}}$ \\
\hline $\begin{array}{c}\text { Dec. 14, 1991 } \\
\text { to }\end{array}$ & 0.000 & -0.021 & -0.089 & 1.47 & 58.95 & $\chi^{2}=239.54$ \\
$(-0.09)$ & $(0.87)$ & $(-0.27)$ & $(0.40)$ & & $\mathrm{F}=52.43$ \\
May 30, 2003 & & & & & & \\
Dec. 14, 1991 & 0.000 & -0.016 & -0.339 & 2.38 & 26.81 & $\chi^{2}=38.27$ \\
to & $(0.25)$ & $(-0.49)$ & $(-0.65)$ & $(-0.36)$ & & $\mathrm{F}=6.51$ \\
May 28, 2003 & & & & & & \\
May 29, 1998 & 0.000 & -0.050 & 0.0015 & 3.079 & 8.71 & $\chi^{2}=58.64$ \\
to & $(0.208)$ & $(-1.11)$ & $(0.00)$ & $(0.55)$ & & $\mathrm{F}=12.55$ \\
Sept. 11, 2001 & & & & & & \\
$\begin{array}{c}\text { Sept. 12, 2001 } \\
\text { to }\end{array}$ & 0.000 & -0.009 & -0.090 & 2.045 & 30.08 & $\chi^{2}=44.33$ \\
May 30, 2003 & & & & & & $\mathrm{F}=9.78$ \\
May 28, 1998 & 0.000 & -0.0140 & -0.071 & 1.296 & 10.71 & $\chi^{2}=95.53$ \\
to & $(0.052)$ & $(-0.40)$ & $(-0.15)$ & $(0.29)$ & & $\mathrm{F}=20.621$ \\
May 30, 2003 & & & & & & \\
\hline
\end{tabular}

a. White test for hetroscedasticity. $H_{0}$ : is the series is homoscedastic. $H_{1}$.is other wise.

b. Ramsey RESET Test. $\mathrm{H}_{0}$ : the functional form is correct. $\mathrm{H}_{1}$ : otherwise. 
Table-5: Random Walk Model with out non-linearities for uncorrected returns for KSE-100 index on weekly basis

$$
\mathbf{R}_{\mathrm{t}}=\alpha_{0}+\alpha_{1} \mathbf{R}_{\mathrm{t}-1}+\varepsilon_{\mathrm{t}}
$$

\begin{tabular}{|c|c|c|c|c|c|}
\hline Periods & $\alpha_{0}$ & $\alpha_{1}$ & $\chi^{2 \mathrm{a}}$ & Q-stats & $\chi^{2 b}$ \\
\hline $\begin{array}{c}\text { Dec. } 14,1991 \\
\text { to } \\
\text { May } 30,2003\end{array}$ & $\begin{array}{l}0.004 \\
(4.73)\end{array}$ & $\begin{array}{l}0.196 \\
(4.39)\end{array}$ & 221.17 & 53 & $\begin{array}{c}\chi^{2}=27.59 \\
F=14.46\end{array}$ \\
\hline $\begin{array}{c}\text { Dec. } 14,1991 \\
\text { to } \\
\text { May } 28,2003\end{array}$ & $\begin{array}{l}-0.001 \\
(-0.71)\end{array}$ & $\begin{array}{l}0.259 \\
(4.23)\end{array}$ & 83.42 & 15 & $\begin{array}{c}\chi^{2}=13.70 \\
F=7.15\end{array}$ \\
\hline $\begin{array}{c}\text { May } 29,1998 \\
\text { to } \\
\text { Sept. 11, } 2001\end{array}$ & $\begin{array}{l}0.000 \\
(0.24)\end{array}$ & $\begin{array}{l}0.097 \\
(1.28)\end{array}$ & 26.67 & - & $\begin{array}{c}\chi^{2}=12.57 \\
\mathrm{~F}=6.66\end{array}$ \\
\hline $\begin{array}{c}\text { Sept. } 12,2001 \\
\text { to } \\
\text { May } 30,2003\end{array}$ & $\begin{array}{l}0.003 \\
(1.67)\end{array}$ & $\begin{array}{l}0.093 \\
(1.47)\end{array}$ & 112.90 & - & $\begin{array}{c}\chi^{2}=16.38 \\
F=8.65\end{array}$ \\
\hline $\begin{array}{c}\text { May } 28,1998 \\
\text { to } \\
\text { May } 30,2003\end{array}$ & $\begin{array}{l}0.002 \\
(1.51)\end{array}$ & $\begin{array}{l}0.103 \\
(1.68)\end{array}$ & 21.45 & - & $\begin{array}{c}\chi^{2}=17.25 \\
F=9.12\end{array}$ \\
\hline
\end{tabular}

a. White test for hetroscedasticity. $\mathrm{H}_{0}$ : is the series is homoscedastic. $\mathrm{H}_{1}$.is other wise.

b. Ramsey RESET Test. $\mathrm{H}_{0}$ : the functional form is correct. $\mathrm{H}_{1}$ : otherwise. 
Table-6: Random Walk Model with out non-linearities for uncorrected returns for KSE-100 index on weekly basis

$$
R_{t}^{\mathrm{adj}}=\alpha_{0}+\alpha_{1} \mathbf{R}_{\mathrm{t}-1}^{\mathrm{adj}}+\varepsilon_{\mathrm{t}}
$$

\begin{tabular}{|c|c|c|c|c|c|}
\hline Periods & $\alpha_{0}$ & $\alpha_{1}$ & $\chi^{2 a}$ & Q-stats & $\chi^{2 b}$ \\
\hline $\begin{array}{c}\text { Dec. } 14,1991 \\
\text { to } \\
\text { May } 30,2003\end{array}$ & $\begin{array}{l}-0.000 \\
(0.06)\end{array}$ & $\begin{array}{l}-0.010 \\
(-0.23)\end{array}$ & 218.87 & 53 & $\begin{array}{l}\chi^{2}=21.91 \\
F=11.376\end{array}$ \\
\hline $\begin{array}{c}\text { Dec. } 14,1991 \\
\text { to } \\
\text { May } 28,2003\end{array}$ & $\begin{array}{l}-0.000 \\
(-0.07)\end{array}$ & $\begin{array}{l}-0.000 \\
(-0.15)\end{array}$ & 86.24 & 25 & $\begin{array}{c}\chi^{2}=9.652 \\
F=4.95\end{array}$ \\
\hline $\begin{array}{c}\text { May } 29,1998 \\
\text { to } \\
\text { Sept. } 11,2001\end{array}$ & $\begin{array}{l}-0.000 \\
(-0.00)\end{array}$ & $\begin{array}{l}-0.001 \\
(-0.01)\end{array}$ & 28.76 & - & $\begin{array}{c}\chi^{2}=12.78 \\
\mathrm{~F}=6.78\end{array}$ \\
\hline $\begin{array}{c}\text { Sept. } 12,2001 \\
\text { to } \\
\text { May } 30,2003\end{array}$ & $\begin{array}{l}0.002 \\
(2.51)\end{array}$ & $\begin{array}{l}-0.014 \\
(-0.22)\end{array}$ & 98.90 & - & $\begin{array}{c}\chi^{2}=14.97 \\
F=7.87\end{array}$ \\
\hline $\begin{array}{c}\text { May } 28,1998 \\
\text { to } \\
\text { May 30, } 2003\end{array}$ & $\begin{array}{l}0.000 \\
(0.00)\end{array}$ & $\begin{array}{l}-0.007 \\
(-0.15)\end{array}$ & 99.80 & - & $\begin{array}{c}\chi^{2}=15.88 \\
F=8.35\end{array}$ \\
\hline
\end{tabular}

a. White test for hetroscedasticity. $\mathrm{H}_{0}$ : is the series is homoscedastic. $\mathrm{H}_{1}$.is other wise.

b. Ramsey RESET Test. $\mathrm{H}_{0}$ : the functional form is correct. $\mathrm{H}_{1}$ : otherwise. 
Table-7: Random Walk Model with non-linearities for uncorrected returns for KSE-100 index on weekly basis

$$
R_{t}=\alpha_{0}+\alpha_{1} R_{t-1}+\alpha_{2} R_{t-1}^{2}+\alpha_{3} R_{t-1}^{3}+\varepsilon_{t}
$$

\begin{tabular}{ccccccc}
\hline Periods & $\alpha_{0}$ & $\alpha_{1}$ & $\alpha_{2}$ & $\alpha_{3}$ & $\chi^{2 \mathrm{a}}$ & $\chi^{2 \mathrm{~b}}$ \\
\hline $\begin{array}{c}\text { Dec. 14, 1991 } \\
\text { to }\end{array}$ & 0.002 & 0.302 & -1.507 & -28.844 & 139.45 & $\chi^{2}=8.757$ \\
$\begin{array}{c}(1.19) \\
\text { May 30, 2003 }\end{array}$ & & & & & & \\
Dec. 14, 1991 & -0.001 & 0.432 & 0.982 & -49.603 & 27.89 & $\chi^{2}=2.175$ \\
to & $(-0.67)$ & $(5.35)$ & $(0.68)$ & $(-2.96)$ & & $\mathrm{F}=1.885$ \\
$\begin{array}{c}\text { May 28, 2003 } \\
\text { May 29, 1998 }\end{array}$ & 0.002 & 0.246 & -3.230 & -50.786 & 65.67 & $\chi^{2}=1.78$ \\
to & $(1.14)$ & $(2.08)$ & $(-1.82)$ & $(-1.49)$ & & $\mathrm{F}=0.88$ \\
$\begin{array}{c}\text { Sept. 11, 2001 } \\
\text { Sept. 12, 2001 }\end{array}$ & 0.007 & 0.093 & -3.463 & -9.602 & 56.08 & $\chi^{2}=5.76$ \\
to & $(2.49)$ & $(0.48)$ & $(-0.88)$ & $(0.17)$ & & $\mathrm{F}=2.97$ \\
$\begin{array}{c}\text { May 30, 2003 } \\
\text { May 28, 1998 }\end{array}$ & 0.004 & 0.197 & -4.111 & -32.542 & 113.90 & $\chi^{2}=6.61$ \\
to & $(2.75)$ & $(2.33)$ & $(-3.27)$ & $(-1.60)$ & & $\mathrm{F}=3.35$ \\
May 30, 2003 & & & & & & \\
\hline
\end{tabular}

a. White test for hetroscedasticity. $\mathrm{H}_{0}$ : is the series is homoscedastic. $\mathrm{H}_{1}$.is other wise.

b. Ramsey RESET Test. $\mathrm{H}_{0}$ : the functional form is correct. $\mathrm{H}_{1}$ : otherwise. 
Table-8: Random Walk Model with non-linearities for uncorrected returns for KSE-100 index on weekly basis

$$
R_{t}^{\mathrm{adj}}=\alpha_{0}+\alpha_{1} R_{\mathrm{t}-1}^{\mathrm{adj}}+\alpha_{2} R^{\mathrm{adj} 2}{ }_{\mathrm{t}-1}+\alpha_{3} \mathrm{R}_{\mathrm{t}-1}^{\mathrm{adj} 3}+\varepsilon_{\mathrm{t}}
$$

\begin{tabular}{ccccccc}
\hline Periods & $\alpha_{0}$ & $\alpha_{1}$ & $\alpha_{2}$ & $\alpha_{3}$ & $\chi^{2 \mathrm{a}}$ & $\chi^{2 \mathrm{~b}}$ \\
\hline $\begin{array}{c}\text { Dec. 14, 1991 } \\
\text { to }\end{array}$ & 0.000 & -0.030 & -0.089 & 0.779 & 245.144 & $\chi^{2}=7.28$ \\
$(0.00)$ & $(-0.52)$ & $(-0.14)$ & $(0.14)$ & & $\mathrm{F}=3.67$ \\
$\begin{array}{c}\text { May 30, 2003 } \\
\text { Dec. 14, 1991 } \\
\text { to }\end{array}$ & -0.000 & -0.036 & -0.272 & -0.444 & 38.70 & $\chi^{2}=1.104$ \\
$\begin{array}{c}\text { May 28, 2003 } \\
\text { May 29, 1998 }\end{array}$ & 0.000 & 0.000 & -0.246 & -0.752 & 67.57 & $\chi^{2}=1.65$ \\
to & $(0.09)$ & $(0.00)$ & $(-0.16)$ & $(-0.32)$ & & $\mathrm{F}=0.819$ \\
$\begin{array}{c}\text { Sept. 11, 2001 } \\
\text { Sept. 12, 2001 }\end{array}$ & 0.007 & -0.322 & 0.176 & 20.21 & 51.62 & $\chi^{2}=4.19$ \\
to & $(0.20)$ & $(-1.21)$ & $(0.77)$ & $(0.76)$ & & $\mathrm{F}=2.12$ \\
$\begin{array}{c}\text { May 30, 2003 } \\
\text { May 28, 1998 }\end{array}$ & 0.001 & -0.097 & -0.403 & 6.155 & 116.66 & $\chi^{2}=6.33$ \\
to & $(0.49)$ & $(-1.19)$ & $(-0.37)$ & $(0.61)$ & & $\mathrm{F}=3.20$ \\
May 30, 2003 & & & & & & \\
\hline
\end{tabular}

a. White test for hetroscedasticity. $\mathrm{H}_{0}$ : is the series is homoscedastic. $\mathrm{H}_{1}$.is other wise.

b. Ramsey RESET Test. $\mathrm{H}_{0}$ : the functional form is correct. $\mathrm{H}_{1}$ : otherwise. 
Table-9: Random Walk Model with out non-linearities for uncorrected returns for KSE-100 index on monthly basis

$$
\mathbf{R}_{\mathrm{t}}=\alpha_{0}+\alpha_{1} \mathbf{R}_{\mathrm{t}-1}+\varepsilon_{\mathrm{t}}
$$

\begin{tabular}{|c|c|c|c|c|c|}
\hline Periods & $\alpha_{0}$ & $\alpha_{1}$ & $\chi^{2 \mathrm{a}}$ & Q-stats & $\chi^{2 b}$ \\
\hline $\begin{array}{c}\text { Dec. } 14,1991 \\
\text { to } \\
\text { May } 30,2003\end{array}$ & $\begin{array}{l}0.025 \\
(1.60)\end{array}$ & $\begin{array}{l}-0.424 \\
(-7.85)\end{array}$ & 205.17 & 15 & $\begin{array}{c}\chi^{2}=128.46 \\
\mathrm{~F}=1133.41\end{array}$ \\
\hline $\begin{array}{c}\text { Dec. } 14,1991 \\
\text { to } \\
\text { May 28, } 2003\end{array}$ & $\begin{array}{l}0.026 \\
(1.06)\end{array}$ & $\begin{array}{l}-0.447 \\
(-6.68)\end{array}$ & 93.89 & 4 & $\begin{array}{l}\chi^{2}=73.16 \\
\mathrm{~F}=1433.21\end{array}$ \\
\hline $\begin{array}{c}\text { May } 29,1998 \\
\text { to } \\
\text { Sept. 11, } 2001\end{array}$ & $\begin{array}{c}0.002 \\
(0.104)\end{array}$ & $\begin{array}{l}-0.053 \\
(-0.37)\end{array}$ & 23.16 & - & $\begin{array}{c}\chi^{2}=4.357 \\
F=2.26\end{array}$ \\
\hline $\begin{array}{c}\text { Sept. } 12,2001 \\
\text { to } \\
\text { May } 30,2003\end{array}$ & $\begin{array}{l}0.073 \\
(1.97)\end{array}$ & $\begin{array}{l}-0.491 \\
(-2.50)\end{array}$ & 108.90 & - & $\begin{array}{c}\chi^{2}=0.32 \\
F=0.14\end{array}$ \\
\hline $\begin{array}{c}\text { May } 28,1998 \\
\text { to } \\
\text { May 30, } 2003\end{array}$ & $\begin{array}{l}0.002 \\
(1.25)\end{array}$ & $\begin{array}{l}-0.255 \\
(-2.17)\end{array}$ & 18.14 & - & $\begin{array}{c}\chi^{2}=3.25 \\
\mathrm{~F}=1.63\end{array}$ \\
\hline
\end{tabular}

a. White test for hetroscedasticity. $\mathrm{H}_{0}$ : is the series is homoscedastic. $\mathrm{H}_{1}$.is other wise.

b. Ramsey RESET Test. $\mathrm{H}_{0}$ : the functional form is correct. $\mathrm{H}_{1}$ : otherwise. 
Table-10: Random Walk Model with out non-linearities for uncorrected returns for KSE-100 index on monthly basis

$$
\mathbf{R}_{\mathrm{t}}^{\mathrm{adj}}=\alpha_{0}+\alpha_{1} \mathbf{R}_{\mathrm{t}-1}^{\mathrm{adj}}+\varepsilon_{\mathrm{t}}
$$

\begin{tabular}{|c|c|c|c|c|c|}
\hline Periods & $\alpha_{0}$ & $\alpha_{1}$ & $\chi^{2 a}$ & Q-stats & $\chi^{2 b}$ \\
\hline $\begin{array}{c}\text { Dec. } 14,1991 \\
\text { to } \\
\text { May } 30,2003\end{array}$ & $\begin{array}{l}-0.001 \\
(-0.07)\end{array}$ & $\begin{array}{l}0.362 \\
(5.51)\end{array}$ & 198.87 & 46 & $\begin{array}{c}\chi^{2}=54.44 \\
F=44.60\end{array}$ \\
\hline $\begin{array}{c}\text { Dec. } 14,1991 \\
\text { to } \\
\text { May } 28,2003\end{array}$ & $\begin{array}{l}-0.012 \\
(-1.06)\end{array}$ & $\begin{array}{l}0.456 \\
(5.70)\end{array}$ & 93.41 & 21 & $\begin{array}{c}\chi^{2}=46.07 \\
F=58.56\end{array}$ \\
\hline $\begin{array}{c}\text { May } 29,1998 \\
\text { to } \\
\text { Sept. } 11,2001\end{array}$ & $\begin{array}{l}-0.000 \\
(-0.08)\end{array}$ & $\begin{array}{l}-0.003 \\
(-0.19)\end{array}$ & 22.17 & - & $\begin{array}{c}\chi^{2}=4.56 \\
F=2.38\end{array}$ \\
\hline $\begin{array}{c}\text { Sept. } 12,2001 \\
\text { to } \\
\text { May } 30,2003\end{array}$ & $\begin{array}{l}-0.003 \\
(-0.13)\end{array}$ & $\begin{array}{c}-0.084 \\
(-0.361)\end{array}$ & 103.90 & - & $\begin{array}{c}\chi^{2}=0.74 \\
\mathrm{~F}=0.32\end{array}$ \\
\hline $\begin{array}{c}\text { May } 28,1998 \\
\text { to } \\
\text { May 30, } 2003\end{array}$ & $\begin{array}{l}0.046 \\
(1.21)\end{array}$ & $\begin{array}{l}-0.281 \\
(-1.24)\end{array}$ & 98.85 & - & $\begin{array}{c}\chi^{2}=0.522 \\
\mathrm{~F}=0.22\end{array}$ \\
\hline
\end{tabular}

a. White test for hetroscedasticity. $\mathrm{H}_{0}$ : is the series is homoscedastic. $\mathrm{H}_{1}$.is other wise.

b. Ramsey RESET Test. $\mathrm{H}_{0}$ : the functional form is correct. $\mathrm{H}_{1}$ : otherwise. 
Table-11: Random Walk Model with non-linearities for uncorrected returns for KSE-100 index on monthly basis

$$
\mathbf{R}_{\mathrm{t}}=\alpha_{0}+\alpha_{1} \mathbf{R}_{\mathrm{t}-1}+\alpha_{2} \mathbf{R}_{\mathrm{t}-1}^{2}+\alpha_{3} \mathbf{R}_{\mathrm{t}-1}^{3}+\varepsilon_{\mathrm{t}}
$$

\begin{tabular}{ccccccc}
\hline Periods & $\alpha_{0}$ & $\alpha_{1}$ & $\alpha_{2}$ & $\alpha_{3}$ & $\chi^{2 \mathrm{a}}$ & $\chi^{2 \mathrm{~b}}$ \\
\hline $\begin{array}{c}\text { Dec. 14, 1991 } \\
\text { to }\end{array}$ & -0.002 & -0.072 & 0.479 & -1.52 & 245.144 & $\chi^{2}=1.59$ \\
May 30, 2003 & & & & & & $\mathrm{F}=0.77$ \\
Dec. 14, 1991 & -0.014 & 0.092 & 0.850 & -4.18 & 38.70 & $\chi^{2}=1.25$ \\
to & $(-1.04)$ & $(0.48)$ & $(1.56)$ & $(-1.96)$ & & $\mathrm{F}=0.61$ \\
May 28, 2003 & & & & & & \\
May 29, 1998 & -0.002 & -0.359 & 0.724 & 5.403 & 67.57 & $\chi^{2}=0.70$ \\
to & $(-0.08)$ & $(-1.48)$ & $(0.68)$ & $(0.40)$ & & $\mathrm{F}=0.33$ \\
$\begin{array}{c}\text { Sept. 11, 2001 } \\
\text { Sept. 12, 2001 }\end{array}$ & 0.052 & -0.511 & 0.6176 & 0.249 & 51.62 & $\chi^{2}=0.66$ \\
to & $(1.15)$ & $(-1.15)$ & $(0.92)$ & $(0.09)$ & & $\mathrm{F}=0.29$ \\
$\begin{array}{c}\text { May 30, 2003 } \\
\text { May 28, 1998 } \\
\text { to }\end{array}$ & 0.014 & -0.155 & 0.285 & -0.769 & 116.66 & $\chi^{2}=2.04$ \\
May 30, 2003 & $(0.68)$ & $(-0.75)$ & $(0.64)$ & $(-0.48)$ & & $\mathrm{F}=1.00$ \\
\hline
\end{tabular}

a. White test for hetroscedasticity. $\mathrm{H}_{0}$ : is the series is homoscedastic. $\mathrm{H}_{1}$.is other wise.

b. Ramsey RESET Test. $\mathrm{H}_{0}$ : the functional form is correct. $\mathrm{H}_{1}$ : otherwise. 
Table-12: Random Walk Model with non-linearities for uncorrected returns for KSE-100 index on monthly basis

$$
R_{t}^{\mathrm{adj}}=\alpha_{0}+\alpha_{1} R_{\mathrm{t}-1}^{\mathrm{adj}}+\alpha_{2} \mathbf{R}_{\mathrm{t}-1}^{\mathrm{adj} 2}+\alpha_{3} \mathrm{R}_{\mathrm{t}-1}^{\mathrm{adj} 3}+\varepsilon_{\mathrm{t}}
$$

\begin{tabular}{ccccccc}
\hline Periods & $\alpha_{0}$ & $\alpha_{1}$ & $\alpha_{2}$ & $\alpha_{3}$ & $\chi^{2 \mathrm{a}}$ & $\chi^{2 \mathrm{a}}$ \\
\hline $\begin{array}{c}\text { Dec. 14, 1991 } \\
\text { to }\end{array}$ & 0.002 & 0.030 & -0.222 & -0.815 & 143.14 & $\chi^{2}=1.54$ \\
$(0.15)$ & $(0.23)$ & $(-0.39)$ & $(-0.41)$ & & $\mathrm{F}=0.76$ \\
$\begin{array}{c}\text { May 30, 2003 } \\
\text { Dec. 14, 1991 } \\
\text { to }\end{array}$ & -0.000 & 0.016 & 0.028 & 0.132 & 23.98 & $\chi^{2}=1.71$ \\
$\begin{array}{c}\text { May 28, 2003 } \\
\text { May 29, 1998 }\end{array}$ & $-0.01)$ & $(0.080)$ & $(0.04)$ & $(0.05)$ & & $\mathrm{F}=0.84$ \\
to & $(-0.39)$ & $(0.68)$ & $(0.86)$ & $(-0.97)$ & & $\mathrm{F}=1.85$ \\
$\begin{array}{c}\text { Sept. 11, 2001 } \\
\text { Sept. 12, 2001 }\end{array}$ & 0.006 & -0.088 & -1.088 & -2.930 & 59.80 & $\chi^{2}=0.52$ \\
to & $(0.20)$ & $(-0.03)$ & $(-0.42)$ & $(-0.31)$ & & $\mathrm{F}=0.23$ \\
$\begin{array}{c}\text { May 30, 2003 } \\
\text { May 28, 1998 }\end{array}$ & 0.001 & 0.008 & -0.067 & -1.789 & 121.60 & $\chi^{2}=0.68$ \\
to & $(0.07)$ & $(0.042)$ & $(-0.08)$ & $(-0.62)$ & & $\mathrm{F}=0.23$ \\
May 30, 2003 & & & & & & \\
\hline
\end{tabular}

a. White test for hetroscedasticity. $\mathrm{H}_{0}$ : is the series is homoscedastic. $\mathrm{H}_{1}$.is other wise.

b. Ramsey RESET Test. $\mathrm{H}_{0}$ : the functional form is correct. $\mathrm{H}_{1}$ : otherwise. 


\section{References}

A1-loughani, N.E., 1995, "Random Walk in Thinly Traded Stock Markets: The Case of Kuwait”, Arab Journal of Administrative Science 3, 189-209.

Anotoniou, A. and N. Ergu1, 1997, "Market Efficiency, Thin Trading and Non-linear Behaviour: Evidence from an Emerging Market", European Financial Management 3:2, 175-190.

Bassett, G.W, Jr, V.G. France and S.R. Pliska, 1991, "Kalman Filter Estimation for valuing non-trading Securities With Application to the MMI Cash Future Spread on Oct. 19 and Oct. 20, 1987”, Review of Quantitative Finance and Accounting, 135-151.

Benartzi, S. and R.H. Thaler, 1995, "Myopic Loss Aversion and the Equity Premium Puzzle," The Quarterly Journal of Economics, MIT Press, Vol. 110(1), 73-92.

Branes, Paul, 1986, "Thin Trading and Stock Market Efficiency: A case of the Kuala Lumpur Stock Exchange”, Journal of Business Finance and Accounting 13:4, 609-617.

Butler, K., and C. Malaikah, 1992, "Efficiency and Inefficiency in Thinly Traded Stock Markets: Kuwait and Saudi Arabia”, Journal of Banking and Finance 16, 197-210.

Cohen, K.J., 1979, "On the Existence of Serial Correlation in an Efficient Securities Market, TIMS”, Studies in the Management Sciences 11, 151-168.

Cohen, K.J., Maier, S.F., Schwartz, R.A. and D.K. Whitcomb, 1978, "The Returns Generation Process, Returns Variance and the Effect of Thinness in Securities Markets", Journal of Finance 33, 149-167.

Cootner, P.H., 1962, "Stock Prices: Random vs Systematic Changes", Industrial Management Review 3, 225-245.

Cowles, A. and H.E. Jones, 1937, "Some Posteriori Probabilities in Stock Market Actions”, Econometrica, 5, 280-294. 
Dickinson, J.P. and K. Muragu, 1994, "Market Efficiency in Developing Countries: A Study of the Nairobi Stock Exchange", Journal of Business Finance and Accounting 21:1, 133-150.

Dimson, E., 1979, "Risk Measurement when Shares are Subject to Infrequent Trading”, Journal of Financial Economics 7, 197-226.

E1-Erian, and M.S. Kumar, 1995, "Emerging Equity Markets in the Middle Eastern Countries”, IMF Staff Papers, IMF, 42:2, 313-343.

Fama, F., 1965, "The Behavior of Stock Market", The Journal of Business, $38,34-105$.

Fisher, I., 1966, “Some New Stock Market Indices”, Journal of Business 39, $191-225$.

Government of Pakistan, 2005-2006, Pakistan Economic Survey, Ministry of Finance.

Grieb, T. and M.G. Reyes, 1999, "Random Walk Tests for Latin America Equity Indices and Individual Firms", Journal of Financial Research 4, 371-383.

Husain, Fazal, 1997, "The Random Walk Model in the Pakistani Equity Market: An Examination”, The Pakistan Development Review 36:3, 221-241.

Lo, A. and A.C. Mackinlay, 1990, "An Econometric Analysis of Infrequent Trading”, Journal of Econometrics 45, 181-211.

Mackinlay, A.C. and K. Ramaswamy, 1988, "Index Feature Arbitrage and the Behavior of Stock Index Futures Prices", Review of Financial Studies $1,137-158$.

Miller, M.H., J. Muthuswamy and R.E. Whaley, 1994, "Mean Reversion of Standard and Poor's 500 Index Basis Changes: Arbitrage-induced or Statistical Illusion", The Journal of Finance 49:2, 479-513.

Muthuswamy, J., 1990, "Non-synchronous Trading and the Index Autocorrelation Problem", PhD Dissertation, Graduate School of Business, University of Chicago. 
Nishat, M. and K. Mustafa, 2007, "Trading Volume and Serial Correlation in Stock Returns in an Emerging Market: A Case Study of Pakistan”, Presented an Pan-Pacific Conference, 2-4 June, Dunedin, New Zealand.

Nishat, M., 1999, “The Impact of Institutional Development on Stock Prices in Pakistan", PhD Dissertation, (unpublished), Auckland Business School, University of Auckland, New Zealand.

Nishat, M., 2000, "The Systemic Risk and Leverage Effect in the Corporate Sector of Pakistan”, The Pakistan Development Review, 39:4, 951962.

Nishat, M., 2001, "Industry Risk Premia in Pakistan", The Pakistan Development Review, 40:4, 929-949.

Ojah, K. and D. Karemera, 1999, "Random Walk and Market Efficiency Tests of Latin American Emerging Equity Markets", The Financial Review 34, 441-468.

Panas, E., 1990, “The Behavior of Athens Stock Prices”, Applied Economics, 22.

Schatzberg, J. D. and Reiber, R. R., 1992, "Extreme Negative Information and the Market Adjustment Process: The Case of Corporate Bankruptcy”, Quarterly Journal of Business and Economics, 31.

Scholes, M. and J. Williams, 1997, "Estimating Betas from Non-synchronous Data”, Journal of Financial Economics 5, 309-327.

Scholes, M., 1976, "Estimating Betas from Daily Data", Working paper, Graduate school of Business. University of Chicago.

Stolls, H.R and Robert E. Whaley, 1990, "Stock Market Structure and Volatility", Journal of Financial and Quantitative Analysis, 25, 441468.

Urrutia, J.L., 1995, "Tests of Random Walk and Market Efficiency for Latin American Emerging Equity Markets" Journal of Financial Research 18, 299-309. 